\title{
PENGARUH STRATEGI POLYA TERHADAP KEMAMPUAN PROSES \\ DALAM LITERASI MATEMATIKA MATERI BANGUN RUANG SISWA KELAS V SD NEGERI 68 KOTA BENGKULU
}

\author{
Igit Setiono'), Agus Susanta' ${ }^{2)}$, Abdul Muktadir ${ }^{3)}$ \\ 1) Mahasiswa Program Studi Pendidikan Dasar, Program Pascasarjana Universitas Bengkulu \\ 2), 3) Dosen Pascasarjana Prodi Pendidikan Dasar Universitas Bengkulu \\ E-mail: igitsetiono@yahoo.com
}

\begin{abstract}
ABSTRAK
Penelitian ini bertujuan untuk mengetahui pengaruh penerapan strategi Polya terhadap kemampuan proses dalam literasi matematika materi bangun ruang siswa kelas V SD Negeri 68 Kota Bengkulu. Jenis penelitian ini adalah penelitian kuantitatif. Adapun metode penelitian yang digunakan adalah kuasi eksperimen dengan menerapkan the matching only pretest-posttest control group design. Sampel penelitian yang diperoleh adalah siswa kelas VA dan VB SD Negeri 68 Kota Bengkulu. Data penelitian diperoleh melalui tes tertulis berupa tes uraian materi bangun ruang yang dapat mengukur kemampuan literasi Matematika pada komponen proses. Analisis data hasil penelitian ini menggunakan analisis inferensial yaitu uji-t. Hasil penelitian menunjukkan bahwa terdapat pengaruh penggunaan strategi Polya terhadap kemampuan konten dalam literasi Matematika materi bangun ruang siswa kelas V SD Negeri 68 Kota Bengkulu.
\end{abstract}

Kata Kunci: Strategi Polya, Bangun Ruang, Kemampuan proses, Literasi Matematika.

\begin{abstract}
This research aims to determine the application effect of Polya strategy on fifth-grade students' process ability in mathematical literacy of solid figure material at SD Negeri 68 Kota Bengkulu. This research was quantitative research. The research method was quasi-experimental by applying the matching only pretest-posttest control group design. The research sample were students of VA and VB grades at SD Negeri 68 Kota Bengkulu. The research data were obtained by using written test describing solid figure material that could measure mathematical literacy skill in process component. Data analysis used inferential analysis (t-test). The result showed that there was using influence of Polya Strategy on process ability in mathematical literacy.
\end{abstract}

Keywords: Polya Strategy, Solid Figure, Process Ability, Mathematical Literacy. 


\section{PENDAHULUAN}

Matematika merupakan salah satu mata pelajaran yang berperan penting dalam membentuk sumber daya manusia yang kompeten untuk menghadapi permasalahan hidup dan tuntutan di dalam masyarakat yang semakin kompleks. Pembelajaran Matematika tidak hanya ditujukan pada peningkatan kemampuan berhitung namun lebih pada peningkatan kemampuan matematis. Menurut Abidin, Mulyati, dan Yunansah (2017:104), literasi Matematis melibatkan pemahaman terhadap aktivitas matematis, penggunaan pengetahuan dan kemampuan matematis, penalaran, serta bahasa untuk menyelesaikan masalah dalam berbagai keadaan dan kebutuhan. Seseorang tidak dapat dikatakan sebagai literat matematis jika tidak mampu menerapkan pengetahuan matematikanya untuk menyelesaikan masalah dalam kehidupan nyata.

Literasi Matematika yang diharapkan menjadi kompetensi yang dikuasai siswa pada semua jenjang pendidikan di Indonesia ternyata belum sesuai dengan harapan. Hal ini dilihat dari skor literasi Matematika siswa Indonesia yang masih dibawah rata-rata internasional. Skor rata-rata internasional menurut PISA untuk matematika pada tahun 2012 adalah 494 sedangkan Indonesia hanya mencapai skor 375. Adapun pada tahun 2015 skor rata-rata internasional adalah 493 dan Indonesia hanya mencapai skor 403. Sebagai perbandingan, siswa di Singapura memperoleh skor sebesar 573 (Abidin, Mulyati, dan
Yunansah, 2017:112). Dari hasil tersebut jelas kemampuan literasi matematika siswa Indonesia masih dibawah rata-rata dan jauh tertinggal dari Negara lain.

Menurut Astuti (2018: 263), literasi matematika diartikan sebagai kemampuan seseorang untuk merumuskan, menerapkan dan menafsirkan matematika dalam berbagai konteks, termasuk kemampuan melakukan penalaran secara matematis dan menggunakan konsep, prosedur, dan fakta untuk menggambarkan, menjelaskan atau memperkirakan fenomena/kejadian. Literasi matematika dikatakan baik apabila ia mampu menganalisis, bernalar, dan mengkomunikasikan pengetahuan dan keterampilan matematikanya secara efektif, serta mampu memecahkan dan menginterpretasikan penyelesaian matematika. Seorang siswa dikatakan mampu menyelesaikan masalah apabila ia mampu menerapkan pengetahuan yang telah diperoleh sebelumnya kedalam situasi baru yang belum dikenal. Sejalan dengan hal itu, Peraturan Menteri Pendidikan Nasional Nomor 22 Tahun 2006 yang juga memuat standar isi mata pelajaran Matematika telah mengakomodir dan selaras dengan pengembangan literasi matematika. Tujuan mata pelajaran matematika disebutkan yaitu agar peserta didik memiliki kemampuan memahami, menggunakan penalaran, memecahkan masalah, mengkomunikasikan dan memiliki sikap menghargai matematika. 
Tuntutan kemampuan siswa dalam matematika tidak sekedar memiliki kemampuan berhitung saja, akan tetapi kemampuan bernalar yang logis dan kritis dalam pemecahan masalah. Pemecahan masalah ini tidak semata-mata masalah yang berupa soal rutin akan tetapi lebih kepada permasalahan yang dihadapi sehari-hari. Seseorang yang literate (melek) matematika tidak sekedar paham tentang matematika akan tetapi juga mampu menggunakannya dalam pemecahan masalah sehari-hari.

Permasalahan pembelajaran Matematika tersebut juga ditemukan di SD Negeri 68 Kota Bengkulu. Menurut pengamatan peneliti, dalam proses pembelajaran terutama mata pelajaran Matematika guru masih menekankan pada keterampilan mengerjakan soal menggunakan rumus tertentu dan siswa hanya terpaku pada contoh yang diberikan guru atau yang ada pada buku paket dari sekolah. Guru hanya menggunakan metode ceramah daripada memberikan kesempatan kepada siswa untuk menemukan sendiri konsep-konsep yang dipelajari. Siswa cenderung pasif, hanya mencatat dan mendengarkan sesuai perintah guru tanpa berupaya untuk menemukan sendiri konsep-konsep yang dipelajari. Pembelajaran menjadi berpusat pada guru sedangkan siswa menjadi pasif karena hanya menunggu rangsangan dari guru.

Rendahnya kemampuan literasi Matematika siswa tersebut perlu mendapat perhatian yang penuh. Berbagai faktor penyebab rendahnya kemampuan literasi
Matematika tersebut perlu ditinjau ulang. Menurut Purwanto (2010: 107), rendahnya prestasi belajar Matematika dipengaruhi oleh beberapa faktor, salah satunya yaitu strategi dan model pembelajaran yang digunakan guru dalam proses pembelajaran. Tidak tepatnya strategi pembelajaran yang digunakan, mengakibatkan siswa sulit menerima materi yang dipelajari. Selain itu adanya anggapan siswa bahwa Matematika adalah pelajaran yang rumit. Hal ini sejalan dengan pendapat Suherman, Winataputra, dan Udin (2003: 67) yang menyatakan bahwa Matematika bersifat abstrak sehingga proses pembelajarannya tidak mudah.

Masalah rendahnya kemampuan literasi Matematika dan hasil belajar Matematika tersebut perlu dicarikan suatu solusi. Salah satu upaya yang dapat dilakukan untuk mengatasi permasalahan tersebut adalah dengan menerapkan strategi pemecahan masalah model Polya dalam proses pembelajaran. Berdasarkan teori Van Hiele dalam Muhsetyo (2007: 1.14), siswa kelas V SD berada pada level 1 dimana pada level ini anak sudah mampu mendefinisikan, mengukur, mengamati, dan menyebutkan sifat-sifat bangun. Hal ini sesuai dengan pendapat Holmes dalam Wardhani, Purnomo, dan Wahyuningsih (2010: 39) bahwa pembelajaran memecahkan masalah pada siswa di kelas tinggi (Kelas IV-VI) harus mempunyai tujuan yang lebih spesifik yaitu siswa mempelajari nama-nama dari urutan 
langkah pemecahan masalah dan belajar cara menerapkannya.

Strategi model Polya merupakan strategi pembelajaran khusus dalam pembelajaran Matematika untuk menyelesaikan soal-soal pemecahan masalah. Pendapat ini diperkuat oleh hasil penelitian Putri (2015: 1994) yang menunjukkan adanya pengaruh yang signifikan antara strategi Polya dan hasil belajar Matematika Siswa kelas V SDN Lidah Kulon IV/467 Surabaya. Penyelesain soal-soal pemecahan masalah dengan menerapkan strategi Polya dalam proses pembelajaran mencakup 4 tahap, yakni : (1) Memahami masalah, (2) membuat rencana penyelesaian, (3) melaksanakan rencana, dan (4) melihat kembali.

Salah satu materi pada pelajaran Matematika kelas V yang banyak diterapkan dalam kehidupan sehari-hari adalah materi bangun ruang. Tidak sedikit benda konkrit ataupun permasalahan yang abstrak di temui di kehidupan sehari-hari siswa menyangkut bangun ruang. Hal ini menarik peneliti untuk melakukan penelitian dengan judul "Pengaruh Strategi Polya Terhadap Kemampuan Literasi Matematika Materi Bangun Ruang Siswa Kelas V SD Negeri 68 Kota Bengkulu”.

\section{Metode Penelitian}

Jenis penelitian yang digunakan dalam penelitian ini adalah penelitian kuantitatif. Adapun Metode yang akan digunakan dalam penelitian ini adalah metode eksperimen. Dalam penelitian ini metode yang dipilih adalah metode eksperimen semu (quasy experiment). Pada kelas eksperimen, pembelajaran akan dilaksanakan dengan menerapkan strategi Polya dan pada kelas kontrol, pembelajaran akan dilaksanakan tanpa menggunakan strategi dan model pembelajaran khusus.

1. Instrumen Penelitian

Instrumen yang peneliti gunakan dalam penelitian ini berupa tes yang berkaitan dengan strategi Polya dan kemampuan literasi Matematika siswa. Tes ini berupa soal uraian yang bermuatan untuk mengukur setiap komponen proses dari literasi Matematika. Soal-soal ini disusun berdasarkan materi pembelajaran yang dilakukan pada kelas eksperimen dan kelas kontrol.

Sebelum dilakukan pretest dan posttest peneliti melakukan validitas terhadap soal yang akan diujikan. Hal ini dilakukan untuk mengukur tingkat kevalidan, reliabilitas, taraf kesukaran, dan daya beda soal. Validitas instrumen yang peneliti lakukan meliputi validitas logis dan validitas empiris.

2. Teknik Pengumpulan Data

Teknik yang digunakan dalam mengumpulkan data pada penelitian ini yaitu tes (pretest dan posttest), dan dokumentasi.

\section{Teknik Analisis Data}

Teknik analisis yang digunakan dalam penelitian ini adalah teknik analisis kualitatif dan analisis kuantitatif. Data hasil validasi ahli dianalisis menggunakan Aiken V. Selanjutnya data kuantitatif adalah data yang diperoleh akan dianalisis dengan menggunakan uji perbedaan dua arah (uji-t), yang bertujuan 
untuk melihat apakah ada pengaruh yang signifikan antara kemampuan literasi Matematika siswa dengan menerapkan strategi Polya. Pengolahan dan analisis data dalam penelitian ini dilakukan terhadap skor pretest dan posttest siswa. Pengolahan dan analisis data yang dilakukan meliputi penentuan skor soal analisis deskriptif, analisis uji prasyarat, dan analisis inferensial.

\section{HASIL}

\section{Deskripsi Data Penelitian}

\section{Hasil Uji Homogenitas Sampel}

Sebelum melaksaakan penelitian di kelas sampel peneliti terlebih dahulu menguji homogenitas dalm bentuk distribusi data antara kelas eksperimen dan kelas kontrol. Pengujian homogenitas ini peneliti lakukan dengan mengambil data hasil ulangan Matematika pada bulan April. Setelah menganalisis data kelas V A dan kelas V B SD Negeri 68 Kota Bengkulu adalah kelas homogen, sehingga dapat dijdikan sebagai kelas sampel penelitian. Adapun hasil distribusi data uji homogenitas data terdapat pada Tabel 1 berikut:

\begin{tabular}{|l|c|c|}
\hline $\begin{array}{c}\text { Aspek yang } \\
\text { Dihitung }\end{array}$ & $\begin{array}{c}\text { Kelompok V } \\
\text { B }\end{array}$ & $\begin{array}{c}\text { Kelompok V } \\
\text { A }\end{array}$ \\
\hline Varian & 29,80 & 21,80 \\
\hline $\mathrm{N}$ & 25 & 25 \\
\hline $\mathrm{F}_{\text {hitung }}$ & \multicolumn{2}{|c|}{1,37} \\
\hline $\mathrm{F}_{\text {tabel }}$ & \multicolumn{2}{|c|}{2,97} \\
\hline Kesimpulan & $\mathrm{F}_{\text {hitung }}<\mathrm{F}_{\text {tabel }}$ (Homogen) \\
\hline
\end{tabular}

Berdasarkan Tabel 1, diperoleh hasil perhitungan varian kelas VB SD Negeri 68 Kota Bengkulu sebesar 29,80 dan kelas VA SD
Negeri 68 Kota Bengkulu sebesar 21,80. Uji-F dilakukan dengan membagi varian terbesar dengan varian terkecil. Dari hasil pembagian tersebut diperoleh $F_{\text {hitung }}$ sebear 1,37 dan nilai $F_{\text {tabel }}$ pada taraf signifikan $5 \%$ sebesar 2,97. Karena $F_{\text {hitung }}<F_{\text {tabel }}$ maka dapat disimpulkan kelas VB dan kelas VA SD Negeri 68 Kota Bengkulu homogen.

2. Pembakuan Instrumen Penelitian

Sebelum melakukan pretest pada kelas sampel peneliti melakukan pembakuan instrumen penelitian terlebih dahulu. Pembakuan intsrumen dilakukan dengan konsultasi dan validasi ahli serta melakukan uji coba lapangan.

a. Validasi Ahli untuk Memvalidkan Soal Validasi ahli dilakukan sebelum peneliti melakukan uji coba lapangan. Uji validasi ahli dilakukan terhadap instrumen soal uraian yang telah dikembangkan peneliti. Instrumen soal yang divalidasi terdiri dari validasi isi soal, validasi konstruks, dan validasi bahasa dalam instrumen soal teebut.

Ahli satu merupakan salah satu dosen tetap di program studi Aktuaria Institut Pertanian Bogor. Ia merupakan ahli dalam pemodelan Matematika. Ahli dua merupakan salah satu dosen tetap di program studi PGSD Universitas Negeri Jakarta yang merupakan dosen ahli di bidang Matematika dan pembuatan soal olimpiade Matematika. Ahli ketiga merupakan Dosen tetap program studi PGSD dan program Pascasarjana Pendidikan Dasar Universitas Bengkulu. Ahli ketiga ini ahli di bidang Bahasa dan Sastra Indonesia. 
Adapun ahli ke empat merupakan salah satu guru senior di salah satu SD Negeri di Kota Bengkulu yang aktif terlibat dalam membimbing siswa-siswa dalam mengikuti Lomba Olimpiade Sains Nasional.

Adapun hasil analisis terhadap data validasi ahli pada masing-masing aspek dapat dilihat dari pada Tabel 2 berikut:

\begin{tabular}{|c|c|c|c|}
\hline No. & $\begin{array}{c}\text { Aspek yang } \\
\text { divalidasi }\end{array}$ & $\begin{array}{c}\text { Nomor } \\
\text { Item }\end{array}$ & $\begin{array}{c}\text { Interpretasi } \\
\text { Validitas }\end{array}$ \\
\hline \multirow{2}{*}{1} & \multirow{2}{*}{ Materi } & 1 dan 2 & Sedang \\
\cline { 3 - 4 } 2 & \multirow{2}{*}{ Konstruksi } & 1 dan 4 & Baik \\
\cline { 3 - 4 } & & 2 & Sedang \\
\hline \multirow{2}{*}{3} & \multirow{2}{*}{ Bahasa } & $\begin{array}{c}1,3,4, \\
\text { dan } 6\end{array}$ & Sedang \\
\cline { 3 - 4 } & & 2 dan 5 & Baik \\
\hline
\end{tabular}

Dari hasil analisis menggunakan formula

Aiken V pada tabel 2 didapat kesimpulan persentase aspek materi sebesar $77 \%$, aspek konstruksi sebesar $78 \%$, dan aspek bahasa 76 $\%$. Berdasarkan hasil analisis dan saran dari para ahli terhadap instrumen, peneliti melakukan revisi instrumen soal.

b. Uji Coba Instrumen

Uji coba instrumen dilakukan di sekolah yang bukan sampel penelitian, yaitu SD Negeri 86 Kota Bengkulu. Dilakukan di sekolah ini dikarenakan SD Negeri 86 merupakan salah satu sekolah yang berada satu gugus dengan sekolah sampel serta diunggulkan. Pada sekolah ini materi bangun

\begin{tabular}{|c|c|c|c|}
\hline coḩatilakukaßre & Post & Pre & Post \\
\hline
\end{tabular}

Analisis uji validitas butir soal, reliabilitas instrumen, taraf kesukaran butir soal dan daya beda butir soal dilakukan dengan bantuan aplikasi SPSS 16.0 dan program microsoft excell 2010. Kriteria validasi butir instrumen berdasarkan nilai hasil perhitungan dengan menggunakan korelasi product moment $\left(r_{x y}\right)$ dan nilai tabel koefisien korelasi product moment $\left(r_{\text {tabel }}\right)$.

\section{Deskripsi Data Kemampuan Literasi Matematika Siswa}

Data hasil penelitian ini didapatkan melalui nilai pretest dan Posttest dari kedua kelompok, yakni kelompok eksperimen dan kelompok kontrol. Pretest dilakukan sebelum memberi perlakuan pada kelas eksperimen yang mengikuti pembelajaran dengan menerapkan strategi model Polya dan pada kelas kontrol yang mengikuti pembelajaran tanpa menerapkan strategi Polya. Sedangkan Posttest dilakukan setelah memberi perlakuan kepada siswa kelas eksperimen yang mengikuti pembelajaran dengan menerapkan strategi model Polya dan pada kelas kontrol yang mengikuti pembelajaran tanpa menerapkan strategi Polya.

Soal pretest dan posttest terdiri dari soal tes uraian yang ditujukan untuk mengukur kemampuan proses dalam literasi Matematika siswa. Tabel 3 berikut adalah data nilai pretest dan Posttest kelompok eksperimen dan kelompok kontrol: 


\begin{tabular}{|c|c|c|c|c|}
\hline & test & test & test & test \\
\hline $\begin{array}{c}\text { Nilai } \\
\text { Tertinggi }\end{array}$ & 49 & 84 & 45 & 77 \\
\hline $\begin{array}{c}\text { Nilai } \\
\text { Terendah }\end{array}$ & 10 & 50 & 10 & 42 \\
\hline Rata-rata & $\begin{array}{c}28,9 \\
6\end{array}$ & 71,22 & 28,58 & $\begin{array}{c}57,7 \\
0\end{array}$ \\
\hline N-Gain & & 0,59 & 0,4 & \\
\hline $\begin{array}{l}\text { Gain } \\
\text { Score }\end{array}$ & \multicolumn{2}{|c|}{42,26} & \multicolumn{2}{|c|}{29,12} \\
\hline $\begin{array}{l}\text { Kesimpul } \\
\quad \text { an }\end{array}$ & \multicolumn{4}{|c|}{$\begin{array}{c}\text { N-Gain dan Gain Score } \\
\text { Eksperimen > N-Gain dan Gain } \\
\text { Score Kontrol }\end{array}$} \\
\hline
\end{tabular}

Berdasarkan data yang disajikan pada

Tabel 3 menunjukkan bahwa pada komponen proses, nilai rata-rata pretest pada kelompok eksperimen dan kelompok kontrol tidak begitu terlihat perbedaannya. Namun ketikaka dilihat dari nilai rata-rata posttest pada kedua kelas dan dilakukan uji Gain didapatkan Gain skor pada kelas eksperimen sebesar 0,59 dan lebih tinggi daripada gain skor pada kelas kontrol yang hanya 0,41. Hal ini berarti bahwa peningkatan nilai pada komponen proses kelas eksperimen lebih tinggi daripada kelas kontrol. Data N-Gain ini juga didukung oleh perbedaan antara Gain Score kelas eksperimen dan Gain Score kelas kontrol. Gain score pada kelas eksperimen lebih tinggi daripada gain score pada kelas kontrol. Hal ini menunjukkan kenaikan skor dari pretest dan posttest pada kelas eksperimen lebih tinggi daripada kelas kontrol.

\section{Pengujian prasyarat Pretest}

1) Uji Normalitas
Pengujian normalitas pada penelitian ini menggunakan rumus Chi Kuadrat. Suatu data dikatakan berdistribusi normal jika hasil perhitungan diperoleh nilai $\mathrm{x}^{2}$ hitung $<\mathrm{x}^{2}$ tabel. Hasil dari perhitungan uji normalitas pada kelompok eksperimen dan kelompok kontrol komponen proses disajikan pada Tabel 4 berikut:

\begin{tabular}{|c|c|c|c|}
\hline Kelompok & $\mathbf{x}^{2}$ hitung & $\mathbf{x}^{2}$ tabel & Distribusi Data \\
\hline Eksperimen & 1,88 & \multirow{2}{*}{11,07} & Normal \\
\cline { 1 - 2 } & & & Normal \\
\hline
\end{tabular}

Berdasarkan data yang diperoleh pada

Tabel 4, hasil uji normalitas pretest kelompok eksperimen dan kelompok kontrol diperoleh, masing-masing $\mathrm{x}^{2}{ }_{\text {hitung }}<\mathrm{x}^{2}$ tabel. Hasil ini menunjukkan bahwa keadaan komponen proses kedua kelompok sebelum diberi perlakuan berdistribusi Normal.

\section{2) Uji Homogenitas}

Setelah mencari kenormalan data selanjutnya adalah menentukan homogenitas data pretest kelompok eksperimen dan kelompok kontrol komponen proses. Pengujian homogentias menggunakan uji F. Sampel dikatakan memiliki varian homogen apabila $F_{\text {hitung }}$ lebih kecil dari pada $F_{\text {tabel }}$ pada taraf signifikan 5\%. Hasil dari perhitungan uji F pada kelompok eksperimen dan kelompok kontrol komponen proses disajikan pada Tabel 5 berikut:

\begin{tabular}{|c|c|c|}
\hline $\begin{array}{c}\text { Deskripsi } \\
\text { Data }\end{array}$ & $\begin{array}{c}\text { Kelompok } \\
\text { Eksprimen }\end{array}$ & $\begin{array}{c}\text { Kelompok } \\
\text { Kontrol }\end{array}$ \\
\hline Varian & 100,04 & 97,11 \\
\hline
\end{tabular}




\begin{tabular}{|l|c|c|}
\hline $\mathbf{N}$ & 25 & 25 \\
\hline $\mathbf{F}_{\text {hitung }}$ & \multicolumn{2}{|c|}{1,03} \\
\hline $\mathbf{F}_{\text {tabel }}$ & \multicolumn{2}{|c|}{2,97} \\
\hline $\begin{array}{l}\text { Kesimpul } \\
\text { an }\end{array}$ & $\mathrm{F}_{\text {hitung }}<\mathrm{F}_{\text {tabel }}($ Homogen $)$ \\
\hline
\end{tabular}

Berdasarkan data yang diperoleh dari

Tabel 5, menunjukkan bahwa nilai $F_{\text {hitung }}$ sebesar 1,39 lebih kecil daripada nilai $F_{\text {tabel }}$ pada taraf signifikan 5\% sebesar 2,97. Artinya kedua data komponen Proses tersebut memiliki varian yang homogen.

\section{3) Uji Hipotesis}

Langkah terakhir dilakukan pengujian hipotesis penelitian yang dilakukan dengan menggunakan uji t-test. Peneliti menggunakan uji t-test karena data $\mathrm{t}$ normal dan homogenitas, yang artinya data tersebut parametrik. Apabila $t_{\text {hitung }}<t_{\text {tabel }}$ berarti tidak terdapat pengaruh Strategi Polya terhadap kemampuan literasi Matematika materi bangun ruang siswa kelas V SD Negeri 68 Kota Bengkulu dan sebaliknya, jika thitung $>t_{\text {tabel }}$ berarti terdapat pengaruh Strategi Polya terhadap kemampuan literasi Matematika materi bangun ruang siswa kelas V SD Negeri 68 Kota Bengkulu. Hasil pengujiaan hipotesis terhadapat kedua kelompok sampel untuk data pretest komponen proses kemampuan literasi Matematika disajikan pada Tabel 6 berikut:

\begin{tabular}{|l|c|c|}
\hline \multirow{2}{*}{$\begin{array}{c}\text { Deskripsi } \\
\text { Data }\end{array}$} & \multicolumn{2}{c|}{ Data } \\
\cline { 2 - 3 } & Eksperimen & Kontrol \\
\hline Rata-rata & 28,96 & 28,58 \\
\hline Varian & 100,04 & 97,11 \\
\hline N & 25 & 25 \\
\hline
\end{tabular}

\begin{tabular}{|l|c|}
\hline $\mathbf{T}_{\text {hitung }}$ & 0,135 \\
\hline $\mathbf{T}_{\text {table }}$ & 2,011 \\
\hline Kesimpulan & $\begin{array}{c}\mathbf{t}_{\text {hitung }}<\mathbf{t}_{\text {tabel}}, \text { maka } \mathbf{H}_{\mathbf{0}} \\
\text { diterima, }\end{array}$ \\
\hline
\end{tabular}

Berdasarkan Tabel 6, diketahui ratarata hasil pretest komponen proses pada kelas eksperimen $=28,96$ dan kelas kontrol $=28,56$. Berdasarkan hasil perhitungan Uji-t pada kelas eksperimen dan kelas kontrol diperoleh $t_{\text {hitung }}=$ 0,135 , dengan taraf signifikansi $\alpha=0,05$ dan $\mathrm{db}=\mathrm{n}_{1}+\mathrm{n}_{2}-2=25+25-2=48$, didapat $\mathrm{t}_{\text {tabel }}=2$ 2,011. Karena $\mathrm{t}_{\text {hitung }}<\mathrm{t}_{\text {tabel }}$, maka $\mathrm{H}_{0}$ diterima, yang artinya tidak ada perbedaan kemampuan awal literasi Matematikan komponen proses antara kelas eksperimen dan kelas kontrol.

\section{Pengujian prasyarat Posttest}

\section{1) Uji Normalitas}

Pengujian normalitas pada penelitian ini menggunakan rumus Chi-Kuadrat. Suatu data dikatakan berdistribusi normal jika hasil perhitungan diperoleh nilai $\mathrm{x}^{2}{ }_{\text {hitung }}<\mathrm{x}^{2}$ tabel. Hasil dari perhitungan uji normalitas data Posttest pada kelompok eksperimen dan kelompok kontrol komponen proses disajikan pada Tabel 7 berikut:

\begin{tabular}{|c|c|c|c|}
\hline Kelompok & $\mathbf{x}^{\mathbf{2}}{ }_{\text {hitung }}$ & $\mathbf{x}_{\text {tabel }}$ & $\begin{array}{c}\text { Distribusi } \\
\text { Data }\end{array}$ \\
\hline Eksperimen & 1,837 & \multirow{2}{*}{11,07} & Normal \\
\cline { 1 - 2 } Kontrol & 2,566 & & Normal \\
\hline
\end{tabular}

Berdasarkan data yang diperoleh pada

Tabel 7, hasil uji normalitas Posttest kelompok eksperimen komponen Proses pada kelompok eksperimen dan kelompok kontrol $\mathrm{x}^{2}$ hitung $<$ 
$\mathrm{x}^{2}$ tabel, hasil ini menunjukkan bahwa keadaan setelah diberi perlakuan pada kelompok eksperimen dan kelas kontrol berdistribusi normal.

\section{2) Uji Homogenitas}

Setelah mencari kenormalan data selanjutnya adalah menentukan homogenitas dapat Posttestt kelompok eksperimen dan kelompok control komponen proses. Pengujian homogentias menggunakan uji F. Sampel dikatakan memiliki varian homogen apabila $\mathrm{f}_{\text {hitung }}$ lebih kecil dari pada $\mathrm{f}_{\text {tabel }}$ pada taraf signifikan 5\%. Hasil dari perhitungan uji-F pada kelompok eksperimen dan kelompok kontrol disajikan pada Tabel 8 berikut:

\begin{tabular}{|l|c|c|}
\hline $\begin{array}{c}\text { Deskripsi } \\
\text { Data }\end{array}$ & $\begin{array}{c}\text { Kelompok } \\
\text { Eksprimen }\end{array}$ & $\begin{array}{c}\text { Kelompok } \\
\text { Kontrol }\end{array}$ \\
\hline Varian & 74,07 & 109,44 \\
\hline $\mathbf{N}$ & 25 & 25 \\
\hline $\mathbf{F}_{\text {hitung }}$ & \multicolumn{2}{|c|}{1,48} \\
\hline F $_{\text {tabel }}$ & \multicolumn{2}{|c|}{2,97} \\
\hline Kesimpulan & $F_{\text {hitung }}<\mathrm{F}_{\text {tabel }}($ Homogen $)$ \\
\hline
\end{tabular}

Berdasarkan data yang diperoleh dari

Tabel 8, menunjukkan bahwa nilai kedua data memiliki varian yang homogen.

\section{3) Uji Hipotesis}

Langkah terakhir dilakukan pengujian hipotesis penelitian yang dilakukan dengan menggunakan uji t-test. Peneliti menggunakan uji t-test karena data $\mathrm{t}$ normal dan homogenitas, yang artinya data tersebut parametrik. Apabila $t_{\text {hitung }}<t_{\text {tabel }}$ berarti tidak terdapat pengaruh Strategi Polya terhadap kemampuan literasi Matematika materi bangun ruang siswa kelas V SD Negeri 68 Kota
Bengkulu dan sebaliknya, jika $t_{\text {hitung }}>t_{\text {tabel }}$ berarti terdapat pengaruh Strategi Polya terhadap kemampuan literasi Matematika materi bangun ruang siswa kelas V SD Negeri 68 Kota Bengkulu. Hasil pengujian hipotesis terhadap kedua kelompok sampel untuk data posttest komponen proses kemampuan literasi Matematika disajikan pada Tabel 9 berikut:

\begin{tabular}{|l|c|c|}
\hline \multirow{2}{*}{$\begin{array}{c}\text { Deskripsi } \\
\text { Data }\end{array}$} & \multicolumn{2}{c|}{ Data } \\
\cline { 2 - 3 } Rata-rata & Eksperimen & Kontrol \\
\hline Varian & 71,22 & 57,70 \\
\hline $\mathbf{N}$ & 25,07 & 109,44 \\
\hline $\mathbf{T}_{\text {hitung }}$ & \multicolumn{2}{|c|}{4,991} \\
\hline $\mathbf{T}_{\text {table }}$ & \multicolumn{2}{|c|}{2,011} \\
\hline Kesimpulan & $\begin{array}{c}\mathbf{t}_{\text {hitung }}>\mathbf{t}_{\text {tabel }}, \text { maka } \mathbf{H}_{\mathbf{a} 2} \\
\text { diterima, }\end{array}$ ditolak \\
\hline
\end{tabular}

Berdasarkan Tabel 9, diketahui rata-rata hasil pretest komponen proses pada kelas eksperimen $=71,22$ dan kelas kontrol $=57,70$. Berdasarkan hasil perhitungan Uji-t pada kelas eksperimen dan kelas kontrol diperoleh $t_{\text {hitung }}$ $=4,991$, dengan taraf signifikansi $\alpha=0,05$ dan $\mathrm{db}=\mathrm{n}_{1}+\mathrm{n}_{2}-2=25+25-2=48$, didapat $\mathrm{t}_{\text {tabel }}=2,011$. Karena $\mathrm{t}_{\text {hitung }}>\mathrm{t}_{\text {tabel }}$, maka $\mathrm{H}_{\mathrm{a}}$ diterima, yang artinya terdapat pengaruh penggunaan strategi Polya terhadap kemampuan proses dalam literasi Matematika materi bangun ruang siswa kelas V SD Negeri 68 Kota Bengkulu.

\section{PEMBAHASAN}

Kemampuan proses dalam literasi Matematika menggambarkan apa yang dilakukan siswa dalam upaya memecahkan 
masalah dalam suatu situasi dengan menggunakan pengetahuan Matematika dan kemampuan yang diperlukan untuk proses tersebut. Proses matematis memerlukan kemampuan-kemampuan pokok yang mendasari sehingga dapat membantu kesuksesan pemecahan masalah. Salah satu komponen yang mendasari kemampuan proses dalam literasi Matematika adalah strategi yang digunakan dalam memecahkan permasalahan. Adapun strategi yang digunakan dalampenelitian ini adalah strategi Polya.

Kemampuan proses dalam penelitian ini diukur dengan melihat proses pemecahan masalah yang berkaitan dengan materi bangun ruang berdasarkan langkah-langkah strategi Polya. Soal yang diberikan untuk mengukurnya adalah soal-soal hitungan tentang menghitung panjang rusuk, luas sisi dan permukaan, serta volume bangun ruang sederhana. Soal disajikan dalam bentuk soal cerita yang berkaitan dengan kehidupan nyata yang sering ditemui siswa di lingkungannya.

Berdasarkan uji hipotesis yang telah dilakukan, dapat diketahui bahwa pada materi bangun ruang siswa yang mengikuti pembelajaran dengan strategi Polya memiliki rata-rata kemampuan proses dalam literasi Matematika yang lebih unggul dibandingkan dengan siswa yang belajar tanpa strategi Polya. Hal ini berarti bahwa terdapat pengaruh yang signifikan penggunaan strategi Polya terhadap kemampuan proses dalam literasi Matematika materi bangun ruang siswa kelas V SD Negeri 68 Kota Bengkulu.
Pada proses pembelajaran di kelas eksperimen diberi perlakuan dengan mengajarkan kepada siswa bagaimana menerapkan strategi Polya dalam menyelesaikan masalah. Mulai dari tahap memahami masalah, membuat rencana penyelesaian, melaksanakan rencana, hingga tahap mengecek kembali. Pembelajaran dengan strategi ini terbukti berhasil dalam meningkatkan kemampuan proses literasi Matematika. Hal ini dibuktikan dengan NGain dan gain skor yang diperoleh siswa sehingga diperoleh peningkatan nilai komponen proses yang signifikan antara tes awal (pretest) dengan tes akhir (posttest) yang dilakukan. Pada nilai pretest rata-rata nilai komponen proses baik kelas eksperimen maupun kelas kontrol sangat rendah. Hal ini disebabkan oleh belum pahamnya siswa tentang materi serta cara penyelesaian masalah tersebut. Namun setelah dilakukan pembelajaran dengan menerapkan strategi Polya pada kelas eksperimen meningkat signifikan dibandingkan dengan kelas kontrol. Pembelajaran dilakukan dengan menerapkan empat langkah Polya. Berbeda dengan kelas kontrol yang tidak diberikan strategi pemecahan masalah model Polya. Pada kelas ini hanya diajarkan rumus-rumus serta latihan mengerjakan soal.

Penilaian terhadap kemampuan proses ini didasarkan oleh langkah-langkah strategi Polya. Langkah pertama dilihat dari kemampuan siswa memahami permasalahan dalam soal. Kemampuan memahami masalah 
dibuktikan dengan siswa mampu menuliskan apa saja yang diketahui serta ditanyakan soal. Pada tahap ini siswa kelas eksperimen secara menyeluruh telah mampu menuliskannyahal yang diketahui dan ditanya soal meskipun dengan bahasa-bahasa yang kurang matematis.

Langkah kedua adalah melihat siswa membuat rencana penyelesaian. Langkah ini dilihat dari bagaimana siswa menuliskan halhal yang siswa ketahui tentang hubungan antar konsep serta rumus atau langkah bagaimana menyelesaikan soal. Pada tahap ini beberapa siswa tidak menuliskan hubungan antar konsep bangun ruang, seperti mengukur luas selimut tabung secara langsung tanpa memberikan penjelasan bahwa mengukur luas selimut tabung sama dengan mengukur luas persegi panjang. Namun dilihat dari kebenaran jawaban sebenarnya siswa telah mampu menghubungkan antar konsep yang berkaitan dengan angun ruang. Hal ini sesuai dengan pendapat Karso (2014: 1.41) yang menyatakan bahwa Matematika memiliki karakteristik berpola pikir deduktif dan disebut juga disebut ilmu tentang hubungan. Berpola pikir deduktif berarti bersifat dari umum ke khusus. Disebut ilmu tentang hubungan dimana antar konsep satu dengan konsep lainnya saling berhubungan.

Langkah ketiga dilihat dari kemampuan siswa melaksanakan rencana yang siswa buat. Juka dibandingkan dengan langkah kedua, langkah ini dapat dikatakan lebih mudah kaerena siswa hanya menghitung dan menjalankan sesuai rencana. Namun pada tahap ini siswa dituntut lebih teliti agar tidak salah dalam menghitung. Hal ini sesuai dengan pendapat Budhi (2005:2) yang menyatakan bahwa langkah melakukan strategi yang dipilih hanya diperlukan kesabaran dan ketelitian.

Langkah ketiga dinilai dari kemampuan siswa mengecek kembali pekerjaanya. Kegiatan mengecek kembali dalam hal ini adalah kemampuan siswa menarik kesimpulan dari pekerjaannya. Secara umum siswa kelas eksperimen telah mampu melaksanakan tahap ini meskipun ada beberapa siswa yang tidak menuliskan kesimpulan di akhir proses pengerjaanya. Menurut Hidayati (2015: 134) kegiatan memeriksa kembali terlaksana apabila siswa telah mampu mengecek hasil jawaban yang didapat dan menarik kesimpulan yang valid.

Pada komponen proses dibutuhkan proses penyelesaian masalah Matematika secara utuh. Pada komponen ini keempat langkah Polya dilaksanakan secara sistematis. Tuntutan komponen proses yang sistematis ini menunjukkan bahwa penerapan strategi Polya dapat meningkatkan proses pemecahan masalah yang bermuara kepada literasi Matematika. Hal ini sejalan dengan pendapat Abidin, Mulyati, dan Yunansah (2017: 99) bahwa kemampuan literasi Matematis adalah kemampuan yang mendukung pengembangan kemampuan menghadapi permasalahan Matematika dalam kehidupan sehari-hari.

\section{Simpulan}


Berdasarkan analisis data dan pembahasan penelitian, simpulan yang dapat ditarik dalam penelitian ini yaitu dengan signifikan $\alpha=5 \%$ terdapat pengaruh yang signifikan penggunaan strategi Polya terhadap kemampuan proses dalam literasi Matematika materi bangun ruang siswa kelas V SD Negeri 68 Kota Bengkulu. Hal ini dikuatkan dengan strategi Polya memberikan bekal berupa langkah-langkah sistematis dalam menyelesaikan persoalan literasi Matematika yang menuntut proses. Langkah sistematis mencakup memahami masalah, membuat rencana penyelesaian, melaksanakan rencana penyelesaian, dan mengecek kembali hasil penyelesaian.

\section{Saran}

Adapun dari simpulan penelitian yang telah dilakukan, saran yang ingin disampaikan sebaiknya guru menggunakan strategi Polya untuk meningkatkan kemampuan proses dalam literasi Matematika agar siswa paham bagaimana menyelesaikan permasalahan Matematika secara sistematis.

\section{DAFTAR PUSTAKA}

Abidin, Y.; Mulyati, T. dan Yunansah, H. 2017. Pembelajaran Literasi (Strategi Meningkatkan Kemampuan Literasi Matematika, Sains, Membaca, dan Menulis. Jakarta: Bumi Aksara.

Astuti, Puji. 2018. Kemampuan Literasi Matematika dan Kemampuan Berpkir Tingkat Tinggi. PRISMA, PROSIDING SEMINAR NASIONAL MATEMATIKA. PRISMA 1 Hal. 263-268. Diunduh pada tanggal 12 April 2018 melalui https://scholar.google.co.id/.
Budi, Wono Setya. 2005. Langkah-langkah awal menuju ke Olimpiade Matematika. Jakarta: Ricardo.

Hidayati, Anisatul. 2015. Proses Penalaran Matematis Siswa dalam Memecahkan Masalah Matematika pada Materi Pokok Dimensi Tiga Berdasarkan Kemampuan Siswa di Sma Negeri 5 Kediri. JURNAL MATH EDUCATOR NUSANTARA. Volume 01 Nomor 02. Diunduh pada tanggal 20 April 2018 melalui https://scholar.google.co.id/

Karso. 2014. Pendidikan Matematika I. Tangerang Selatan: Universitas Terbuka.

Muhsetyo, Gatot. 2007. Pembelajaran Matematika SD. Tangerang Selatan: Universitas Terbuka.

Purwanto, M.N. 2010. Psikologi Pendidikan. Bandung: PT. Remaja Rosdakarya.

Putri, N.A.S. 2015. Pengaruh Strategi Polya Terhadap Hasil Belajar Mata Pelajaran Matematika Pada Siswa Sekolah Dasar. JPGSD. Volume 03 Nomor 02. Diunduh pada tanggal 24 Maret 2018 melalui https://scholar.google.co.id/

Rakyat Bengkulu. 2017. Kota tertinggi Kaur Terendah. Diunduh pada tanggal 20 Januari 2018 pukul 21:00 melalui web: http://harianrakyatbengkulu.com/ver3/20 17/06/16/kota-tertinggi-kaur-terendah/

Suherman. E, Winataputra dan Udin, S. 2003. Strategi Belajar Mengajar Matematika. Jakarta. Departemen Pendidikan dan Kebudayaan.

Wardhani, S.; Purnomo, S.S.; Wahyuningsih, E. 2010. Pembelajaran Kemampuan Pemecahan Masalah Matematika di SD. Jakarta: PPPPTK Matematika. 